\title{
How Overtourism Threatens Large Urban Areas: A Case Study of the City of Wroctaw, Poland
}

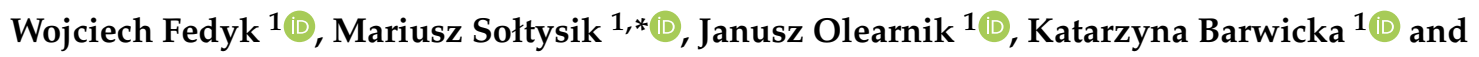 \\ Anna Mucha ${ }^{2}$ D \\ 1 University School of Physical Education in Wrocław, al. I.J. Paderewskiego 35, 51-612 Wrocław, Poland; \\ wojciech.fedyk@awf.wroc.pl (W.F.); janusz.olearnik@awf.wroc.pl (J.O.); \\ katarzynabarwicka@gmail.com (K.B.) \\ 2 Wrocław University of Environmental and Life Sciences, ul. Kożuchowska 7, 51-631 Wrocław, Poland; \\ anna.mucha@upwr.edu.pl \\ * Correspondence: mariusz.soltysik@awf.wroc.pl; Tel.: +48-607-632-798
}

Received: 11 February 2020; Accepted: 25 February 2020; Published: 27 February 2020

check for updates

\begin{abstract}
Excessive tourist traffic concentration in cities of high tourist attractiveness often leads to overtourism, manifested, among others, by overcrowding in appealing areas and means of transport, rising prices, or degradation of natural and cultural resources. The effects of an excessive number of tourists include an unfavourable change in the local community's attitude towards tourists. The paper determines the extent and forms of overtourism symptoms in Wrocław, Poland. The research allowed for the identification of negative and positive effects of tourist traffic in Wrocław as perceived by three groups of respondents: experts, Wrocław residents: key experts from the scientific, administrative, planning, and business communities; people directly involved in tourist services; and students of tourism. The crucial part was direct research, conducted in November 2019 with a questionnaire technique. The results confirm symptoms of overtourism in Wrocław, but the threat is not significant. The article shows specific potential overtourism threat factors; the respondents' opinions did not significantly differ between the groups. The presented findings and conclusions may be useful in developing the tourism policy of this and other cities, especially regarding sustainable development of tourism and the potential threat imposed by overtourism. The methodology may be used in similar comparative studies in other cities.
\end{abstract}

Keywords: sustainable tourism; overtourism; urban tourism; Wrocław city; Poland

\section{Introduction}

The aim of the study was to identify the background and factors contributing to the overtourism phenomenon in a big urban agglomeration of high tourist attractiveness. The research object was Wrocław, a city of over 600,000 inhabitants, located in the west of Poland (Figure 1), a popular tourist destination for people from various countries. This is a city with a still growing reputation.

The tourist resources and potential of Wrocław are based primarily on its centuries-old and highly diversified cultural heritage and unique architecture as well as a rapidly developing meeting industry infrastructure. This determines the key forms and types of tourist traffic in the city space (such as cultural tourism, city breaks, and business and conference tourism). The number of tourists visiting the city is constantly and dynamically increasing. According to estimates [1,2], in 2018, 5.35 million tourists were registered in Wroclaw, with a constant increase in the group of foreign tourists and an overall increase in the number of tourists of $+7 \%$ in the period of 2016-2018. The number of tourists utilizing the accommodation facilities in Wrocław increased by as much as 40\% in the period of 2014-2018, with the concentration of tourist traffic flows in May-August (at the level of 52\% of the registered traffic) [3]. 


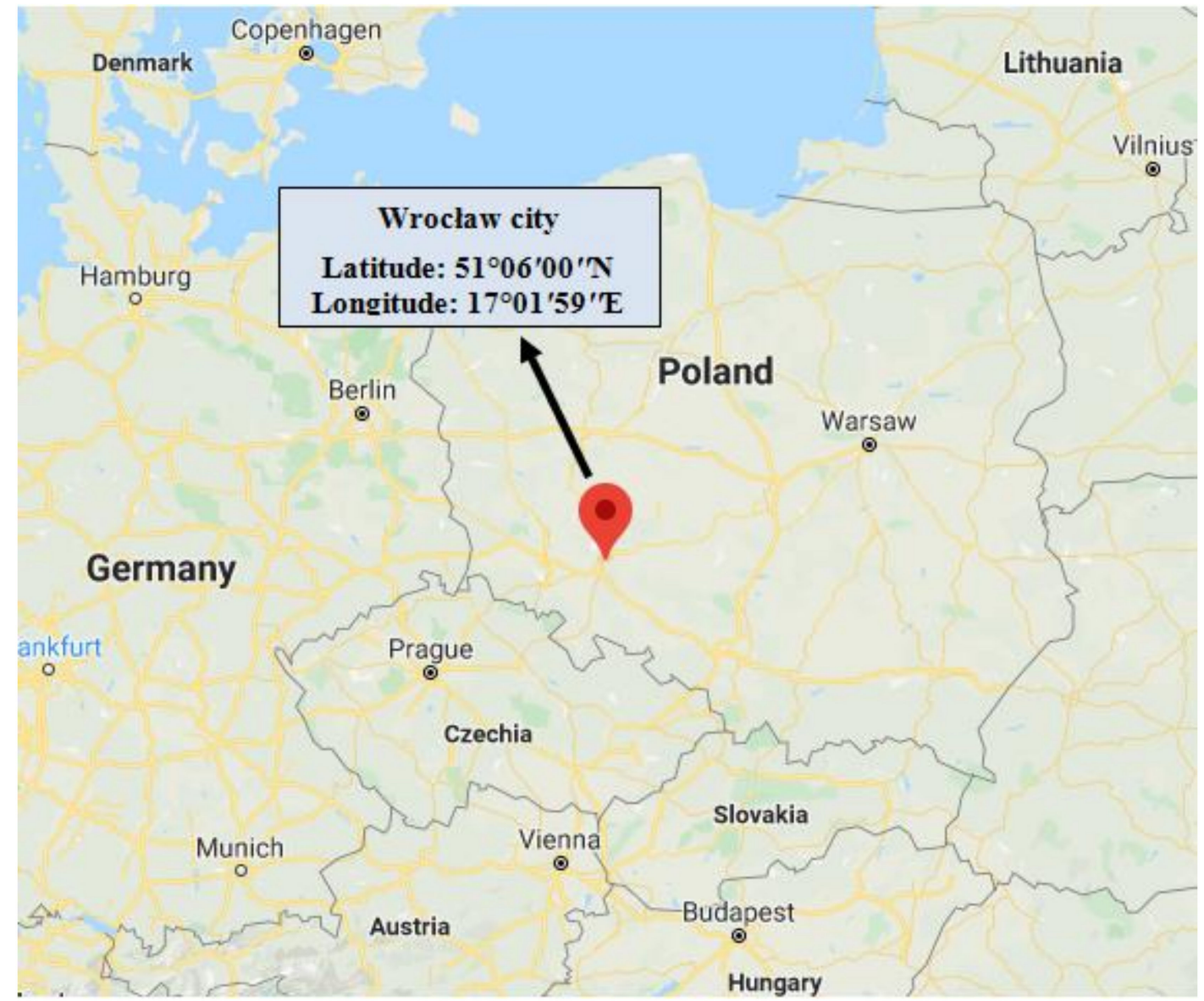

Figure 1. Geographical location of Wrocław. Source: own elaboration based on Google Maps.

Wrocław was ranked "Gamma-" in the prestigious international ranking of the British Loughborough University, The World According to GaWC 2018, (Globalization and World Cities Research) [4], which denotes a high position among the world's leading cities. In the Polish Premium Brand 2019 classification, Wrocław was ranked first as a province capital city, enjoying the best reputation among Poles [5]. It was also placed 95th of the 174 cities assessed in the ranking of the world's smartest cities published in 2019 in the annual report of IESE Business School University of Navarra, Cities in Motion Index [6].

On the basis of the available diagnoses [1], we made the initial assumption that there were symptoms of overtourism in Wrocław, which might intensify in the years to come. We intended to establish the degree of overtourism threat and to determine factors increasing and decreasing the threat, as perceived by people working for the benefit of tourism and living in Wrocław.

Overtourism is an objective phenomenon that emerges as a result of tourism market activity and socioeconomic policy. Its negative consequences affect mainly the tourists themselves and the residents of a given area, although they may, to a certain extent, be approved by entrepreneurs involved in tourism. Three main types of activities related to this phenomenon can be identified. The first one is preventing the emergence of overtourism. These are preventive measures involved in the development strategies of cities and regions. The second type of actions entails measures to eliminate or reduce the adverse effects of overtourism. Here, special action plans are needed, usually long-term ones. The third type is adaptation activities, whereby one wants to adjust the functioning of a given area to excessive tourist traffic, accepting its existence. Each of these types of action requires a preliminary multidirectional diagnosis of overtourism, recognition of its specific elements, as well as an early identification of risks and their potential consequences. In this paper, we focus on this third aspect. The examined city has no conclusive overtourism data, measurements, or assessments. The available 
scarce analyses relating to the description of the tourist phenomena in Wrocław which can be seen as symptoms of overtourism are prognostic in their character [1,2]. Simultaneously, the analyses in question directly indicate the content (Strengths, Weaknesses, Opportunities, Threats: SWOT analysis), and even specific operational objectives and a catalogue of actions within the planned tourist policy of the city, which are aimed at reducing the overtourism phenomenon [1]. This indirectly proves the need to verify the real condition of the overtourism phenomenon in the city space. There is not enough evidence to infer that this phenomenon has already become a real threat. An ongoing discussion of experts (being also Wrocław residents) reveals suggestions of potential discomfort caused by the growing tourist traffic in Wrocław. The city authorities consider whether to stimulate further tourist traffic development or perhaps to inhibit it [1]. Therefore, a closer examination is becoming increasingly important, including verification and assessment of the opinions and feelings of main tourism stakeholders in Wrocław. In recent years, Wrocław has taken steps to stimulate some areas of the city in order to increase the significance of the tourist function. This created incentives and opportunities for tourist traffic growth. It is thus worth seeking an answer to the question of whether this direction should be further followed in the coming years.

\section{Literature Review}

Overtourism is an issue of interest for politicians, managers, researchers, and tourists. It is typically discussed in the context of sustainable development, and, specifically, sustainable tourism. Although the concept of sustainable development remains fairly ambiguous [7], it has been gradually implemented in various economic sectors, including tourism industry, where it has led to the idea of sustainable tourism.

The issue of sustainable tourism has been analysed by many researchers, both in the theoretical field [8-15] and in case studies aimed at illustrating its practical dimension [16-19]. Butler [10] presented sustainable tourism as "tourism which is developed and maintained in an area (community, environment) in such a manner and at such a scale that it remains viable over an infinite period and does not degrade or alter the environment (human and physical) in which it exists to such a degree that it prohibits the successful development and well-being of other activities and processes". Sustainable tourism is a way of organizing and managing the tourism industry $[14,20,21]$ in which determining the acceptable level of tourist traffic growth is a very important assumption [14].

Having that in mind, one can observe not only an intensification of the effects of classical tourism dysfunctions but also the emergence of new, unfavourable consequences of tourist traffic mismanagement, including what is known as overtourism.

Though not a new phenomenon [22-27], overtourism has recently become a "buzzword", appearing in quite numerous scientific discourses, popular scientific presentations, or mass media, including news. Along with the growth of tourism popularity and hypermobility, the burning issue of "tourism saturation" [25] has emerged. This phenomenon is often discussed as it pertains to large urban agglomerations, such as Barcelona, Venice, or Berlin, whose residents openly protest against what they call "tourism flooding", "tourism invasion", or even "tourism pollution". In some tourist destinations, an unflattering atmosphere has aroused around tourists, which is referred to in scientific literature as "tourismophobia" $[25,27,28]$.

Overtourism, now constituting a global problem [25], has been defined as "the impact of tourism on a destination, or parts thereof, that excessively influences perceived quality of life of citizens and/or quality of visitors experiences in a negative way" [29]. Milano et al. [26] define it as "the excessive growth of visitors leading to overcrowding in areas where residents suffer the consequences of temporary and seasonal tourism peaks, which have caused permanent changes to their lifestyles, denied access to amenities and damaged their general well-being".

Despite a quite agreed-upon approach to the definition framework, overtourism is a complex phenomenon [26] and it does not simply stand for the number of tourists visiting a particular destination but for the issue of tourist capacity [24]. Since the phenomenon of "overloved cities" 
results from short-sighted tourism policy and poor management focused on generating maximum possible income [30], it causes a number of annoying consequences, e.g., overcrowding, degradation of both cultural and nature sites, low quality of tourists' experience, residents' dissatisfaction due to the increase in the prices of services, apartments, and real estate, and gentrification of the cities [24].

In the scientific literature, the problem of overtourism has been described many times in the context of big cities and well-known tourist destinations. Besides the flagship examples of Barcelona, Venice, Florence, Amsterdam, and Berlin, the following cases have also been mentioned:

- Cambodia, Costa Rica, US, France, Dubai, Zambia, Sri Lanka, China [31];

- $\quad$ Palma de Mallorca, Paris, Dubrovnik, Kyoto, Bali, Reykjavik, Thailand [25];

- Majorca, Galapagos Islands, Kyoto, Iceland, Costa Rica, Favelas in Rio de Janeiro, Portuguese urban cities, Byron Bay-Australia, Greenland [26];

- Cairo, Delhi, Manila, Bangkok, Moscow [32];

- Rome, Prague, and in Poland, among others: Zakopane (Krupówki Street), the Tatra Mountains (Morskie Oko lake), Kraków, Kazimierz Dolny, Śnieżka mountain, Wieliczka Salt Mine, or the Auschwitz-Birkenau Memorial and Museum [24,33].

Implementing potential solutions for the consequences of overtourism is a complex task that requires long-term strategic planning. It has been noted that "there is a pressing need to set a sustainable roadmap for urban tourism and position the sector in the wider urban agenda" [29]. The United Nations World Tourism Organization (UNWTO) [29] has proposed 11 strategies that may help limit the overtourism consequences:

- $\quad$ promote the dispersal of visitors within the city and beyond;

- promote time-based dispersal of visitors;

- stimulate new visitor itineraries and attractions;

- review and adapt regulations;

- enhance visitor segmentation;

- ensure local communities benefit from tourism;

- create urban experiences that benefit both residents and visitors;

- improve city infrastructure and facilities;

- engage and communicate with local stakeholders;

- engage and communicate with visitors;

- $\quad$ establish monitoring and response measures.

The elements of the strategies limiting the negative impact of overtourism indicated by UNWTO [29] are included in the conceptual assumptions of tourism development in Wrocław up to 2023 [1] in the following aspects: the city tourist mission, strategic areas of tourism development and expectations of stakeholders, as well as the adopted strategic and operational objectives together with selected activities.

According to Séraphin et al. [27], branding is a very important tool to prevent the effects of overtourism by creating the desired image of a given tourist destination, e.g., by "appealing to target audience's emotional aspirations" or educating tourists [27]. The question arises as to how many destination marketing organisations use this educative function of branding to induce desired behaviours in tourists. What exactly would its efficiency depend on [34-40]?

Kruczek [24] indicates that overtourism is a "side effect" of mass tourism, affecting mostly (but not only) local communities and the natural environment. The need to move away from traditional mass tourism has been reflected in the demands for a paradigm change from the so-called $3 S$ tourism (Sun, Sand, Sea) to 3E tourism (Entertainment, Excitement, Education) (e.g., [41]), bringing about sustainable tourism (e.g., [8,14]), various forms of alternative tourism [42,43], or ecotourism [44,45].

The greening of mass tourism $[46,47]$ and the large-scale promotion of sustainable forms of travelling can prove to be effective ways not only to avoid the effects of overtourism but also to 
implement a more sustainable policy in cities, to improve the quality of life of host communities, and to raise the quality of the tourism experience.

The approach selection and strategy clarification require determination of whether overtourism is only a potential threat to a given area (destination) or a reality already. In the former case, preventive strategies should be pursued to inhibit any imbalances; in the latter situation, strategies to mitigate or eliminate the adverse effects of overtourism are essential. In any case, it is necessary to provide a diagnosis, preferably through repeated direct research in a particular location. This requires ongoing research and observation in places at risk of or already affected by overtourism, especially from the perspective of parties concerned with the phenomenon. The aim is to properly recognize the expectations and feedback of residents, the tourist industry, local authorities, and tourists themselves.

The presented paper is based on such research, which reveals the opinions of key experts, people working for the benefit of tourism, and residents, i.e., important groups of stakeholders in tourism development.

Wrocław is conveniently located in terms of tourist traffic routes and transport connections, has an interesting past, a wealth of unique monuments of history, and recognized tourist attractions. It is also a place of important events and meetings. These are among the reasons why Wroclaw is one of the Polish centres attracting tourists from various countries; it is estimated that the city is visited by more than 5 million people each year [2]. It should be noted that no studies on threats of overtourism have been carried out in Wrocław so far; therefore, the survey undertaken here (limited to a specific group of respondents, treated as experts) may be considered as the first approach to diagnosing the overtourism problem.

\section{Material and Methods}

The research carried out was twofold. Initially, the desk research method was applied, the analysis of secondary and primary data (subject literature, strategies and plans for tourism development in Wrocław $[48,49]$, reports from the tourist traffic survey, Statistics Poland data, website data). The authors reviewed scientific publications on conditions of tourism development in urban entities and agglomerations, processes of sustainable development of tourism economy in large cities, and the effects of tourism concentration (including overtourism) in urban space.

Direct research was of key methodological importance. It was conducted in Wrocław in November 2019 as a questionnaire survey and aimed at a preliminary recognition of the investigated overtourism phenomenon. The research was performed in three stages. The first stage was a pilot study (questionnaire test) involving 10 key experts: representatives of Wrocław city authorities and local government (directors of tourism development offices), business communities (including representatives of tourism industry associations), academic communities (of recognized position in the research of tourist phenomena), and planning institutions (actively occupied with creating the sphere of tourism in Wrocław). The second stage was to collect opinions (on the basis of a survey questionnaire) of people directly involved in tourist services (90 persons: tour guides and tour leaders, also affiliated with the industry associations, as well as organizers of the incoming tourism to Wrocław), whom we treat as experienced observers and tourist experts with established views on tourist phenomena taking place in urban space. The third stage of the survey (survey questionnaire) involved students of tourism (60 persons: Wrocław residents), as a group of additional experts, having in-depth knowledge of tourist traffic, as well as a more critical view of the current phenomena in tourism. It is important that the respondents (experts) were residents of Wrocław.

Purposive sampling was applied with the consideration of the respondents' suitability for assessing the potential overtourism. It should be emphasized that the essence and purpose of the research was not to measure the entire population, as it was a qualitative study aimed at identifying and describing the phenomenon of overtourism on the basis of the opinions of people actively involved in tourism services or constantly observing the market for these services. The sample size in the survey was 
not substantial since the key variables in the selection of respondents were their competences and experience which would guarantee deepened opinions on the manifestations of overtourism.

Direct research with key experts was carried out by using the computer-assisted web interview method; in surveying people directly involved in providing services to tourists (tourist experts), we employed official meetings organized by the Wrocław authorities to present directions of tourism development. The additional experts, a group of students, were selected from among the best students of tourism (master's degree).

The research was based on a questionnaire with 13 groups of variables. The variables included:

- the impact of tourism on the environment, economic development, community, tourist assets and infrastructure, commuting and transport, city tourist offers;

- symptoms of a negative tourist traffic impact on the city space (uneven development of nontourist districts, disparities in the development of districts, pauperisation of nontourist areas);

- tourism features influencing the characteristics of Wrocław;

- the residents' level of satisfaction with living in Wrocław;

- phenomena related to sharing economy, especially creating an offer for temporary apartment rental in Wrocław;

- the image of the city in the eyes of its residents;

- the phenomenon of moving out of Wrocław or its districts as a result of increased tourist traffic;

- the city's gentrification processes.

The purpose of the empirical research conducted in this manner was to identify the negative and positive effects of tourist traffic in Wrocław, particularly in terms of sustainable development of tourism as well as the potential threats to this process resulting from overtourism.

The statistical analysis of the survey results was conducted by using the R 3.5.3 software [50]. The response rate diagrams were obtained in the likert [51] package in R. In order to present a comprehensive picture of the results, the following calculations were performed: the mean rate of positive and negative indications for the main research issues for the groups of tourist experts and additional experts (hereinafter referred to as other experts) $\left(\mathrm{M}_{\mathrm{ro}}\right.$-mean rate of other experts' responses) and key experts $\left(\mathrm{M}_{\mathrm{re}}\right.$-mean rate of key experts' responses), the coefficient of variation for other experts $\left(V_{o}\right)$ and key experts $\left(V_{e}\right)$, as well as the mean point values $\left(\mathrm{M}_{p v 1-5}\right.$ or $\left.M_{p v 1-7}\right)$ of opinions for particular detailed questions, expressed in the ranges of 1-5 and 1-7.

The analysis of the significance of differences in the rates of particular responses was also carried out and verified with a Fisher's exact test, with the statistical significance level of $\alpha=0.05$. In turn, the significance of differences in the mean point values ascribed to particular responses was verified with the Wilcoxon test, with the statistical significance level of $\alpha=0.05$. An analysis of the correlation of total scores was performed for 5 content-related questions from the survey questionnaire. The total scores were determined by summing up all responses of a respondent separately for each of the indicated questions and then scaling them to the $[0 ; 100]$ range by using the following formula:

$$
\frac{\text { sum of points }- \text { minimum sum of points }}{\text { maximum sum of points - minimum sum of points }} \times 100
$$

In drawing conclusions, the methods of deduction and comparative analysis with the technique of describing diversity and similarities were applied. In order to simplify the problem presentation, the obtained data were aggregated, limiting the number of presented observations to key results only. The authors also relied on their own observations and experiences as professional and active participants in the system of planning, managing, organizing, and servicing the tourist traffic in Wrocław (observation participant method). 


\section{Research Results}

A total of 160 respondents (including 10 key experts) for whom Wrocław was a place of residence and work (85\%) participated in the study. As already indicated, the sampling was purposive and qualitative. The survey was carried out in the same period (November 2019) for the three types of respondent groups.

Almost half of the surveyed residents were aged 24 years or less $(46.25 \%), 16.25 \%$ were aged $25-45$ years, and $37.5 \%$ were aged 45 years or more. A vast majority $(67.5 \%)$ of the participants worked in the field of tourism, representing several service categories: organization and servicing of tourist traffic $(52.5 \%)$, accommodation and catering services $(15 \%)$, and tourism-related services $(26.88 \%)$ (Table 1).

Table 1. Structure of respondents.

\begin{tabular}{cc}
\hline \multicolumn{2}{c}{ Wrocław Residents } \\
\hline Permanent residence & $20.00 \%$ \\
City of professional activity & $15.00 \%$ \\
City of residence and work & $65.00 \%$ \\
\hline \multicolumn{1}{c}{ Age } \\
\hline 15-24 years & $46.25 \%$ \\
25-44 years & $16.25 \%$ \\
45-64 years & $25.62 \%$ \\
$\geq 65$ years & $11.88 \%$ \\
\hline Tourist traffic organization and services & \\
Hospitality services & $52.50 \%$ \\
Catering & $6.25 \%$ \\
Transportation services & $8.75 \%$ \\
Other tourist services & $4.38 \%$ \\
Other services & $26.88 \%$ \\
\hline
\end{tabular}

Source: own elaboration.

The assessment of the impact of tourist traffic on the survey respondents (Wrocław residents) was carried out with reference to seven types of city functioning spheres; this division reflects the areas of potential overtourism impact on urban agglomerations indicated in the literature. The respondents' evaluations of the nature and degree of tourist traffic intensity impact on Wrocław, expressed on a 5-degree scale, indicate that symptoms of negative impact of tourism are noticeable but in a widely varying degree. Negative opinions ranged from $10 \%$ to $50 \%$ among key experts and from $7 \%$ to $34 \%$ among other experts (Figure 2). In terms of all seven investigated variables (Figure 2), the mean score for the opinions confirming the overtourism symptoms observed by the respondents was $\mathrm{M}_{\mathrm{ro}}=66.0 \%$ $\left(V_{\mathrm{o}}=12.9\right)$ for other experts and $\mathrm{M}_{\mathrm{re}}=68.6 \%\left(\mathrm{~V}_{\mathrm{e}}=24.4\right)$ for key experts. The mean rate of opinions denying the existence of such symptoms equalled $\mathrm{M}_{\mathrm{ro}}=26.1 \%\left(\mathrm{~V}_{\mathrm{o}}=53.5\right)$ among other experts and $\mathrm{M}_{\mathrm{re}}=27.1 \%\left(\mathrm{~V}_{\mathrm{e}}=55.1\right)$ among key experts with regard to the perception and feeling of the impact of tourist traffic on the functioning of the city. The values of the coefficient of variation indicate significant differences in the indications in both studied groups in terms of the intensity of the respondents' indications for particular variables. It can be presumed that the magnitude of the diversity of opinions in the surveyed populations of other experts and key experts may be derived from and correlated with their area of residence and age. However, in this case, such relationships and correlations were not subject to the statistical analyses. 


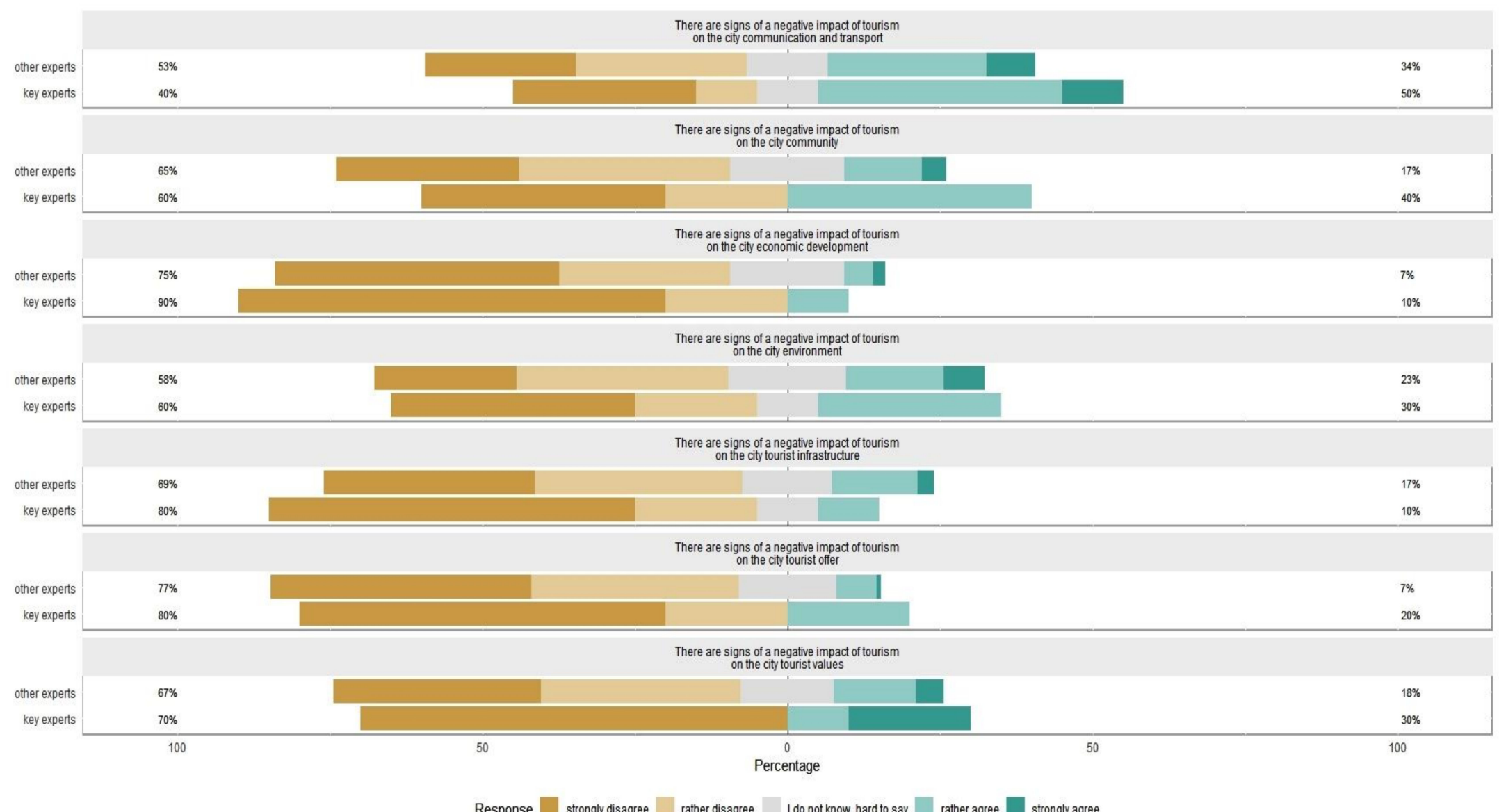

Figure 2. Comparison of other experts' and key experts' attitudes regarding the negative impact of tourism on the functioning of Wrocław. Source: own elaboration. 
It is worth noting the manifestations of overtourism perceived by the respondents (mainly congestion, noise, queues for services) in relation to the negative impact of tourism on $\left(\mathrm{M}_{\mathrm{pv}}\right.$ in a scale of $\left.1-5\right)$ :

- commuting and public transport: $50 \%$ key experts, $34 \%$ other experts $\left(\mathrm{M}_{\mathrm{pv}}=2.66\right)$;

- the life of the city community: $40 \%$ key experts, $17 \%$ other experts $\left(\mathrm{M}_{\mathrm{pv}}=3.25\right)$;

- the natural environment of the city: $30 \%$ key experts, $23 \%$ other experts $\left(\mathrm{M}_{\mathrm{pv}}=2.47\right)$;

- the city tourist assets: $30 \%$ key experts, $18 \%$ other experts $\left(\mathrm{M}_{\mathrm{pv}}=2.21\right)$.

At the same time, the respondents widely denied opinions about the negative impact of tourist traffic on:

- the city tourist infrastructure: $80 \%$ key experts, $69 \%$ other experts $\left(\mathrm{M}_{\mathrm{pv}}=2.13\right)$;

- the city tourist offers: $80 \%$ key experts, $77 \%$ other experts $\left(\mathrm{M}_{\mathrm{pv}}=2.21\right)$;

- the city economic development: $90 \%$ key experts, $75 \%$ other experts $\left(\mathrm{M}_{\mathrm{pv}}=1.85\right)$ (Figure 2).

The results of the research allow for a careful conclusion that the respondents tended to believe that tourism had a positive impact on the city functioning (mean of positive opinions: $66.2 \%$ ) but at the same time they began to notice the phenomena which might have a negative impact on the Wrocław urban space, with the constantly growing tourist traffic (5.35 million in 2018, with an increase by $11 \%$ compared with 2017) [2]. However, the range of negative assessments, i.e., those that strongly emphasized the threat of overtourism, should be considered as relatively small.

The respondents were also asked to indicate some key problems related to the impact of tourist traffic on the city as well as to assess the strength of the impact and the severity of the problem on a scale of +3 to -3 (Figure 3). The results indicate that among both other experts and key experts, positive opinions prevailed in relation to particular issues reflecting the probable difficulties that might occur in the city as a result of the concentrated tourist traffic. However, the differences between the mean values of negative and positive indications (determined on the basis of the responses) were slightly significant in this case. In general, as indicated by the respondents, the biggest problems of the city due to tourist traffic $\left(\mathrm{M}_{\mathrm{pv}}\right.$ on a scale of 1-7) were the following: lack of parking lots- $56.6 \%$ of indications $\left(\mathrm{M}_{\mathrm{pv}}=4.66\right)$, excessive air pollution-55.6\% of indications $\left(\mathrm{M}_{\mathrm{pv}}=4.40\right)$, too high housing prices $-53.1 \%$ of indications $\left(\mathrm{M}_{\mathrm{pv}}=4.34\right)$, city traffic congestion $-53.7 \%$ of indications $\left(\mathrm{M}_{\mathrm{pv}}=4.53\right)$, excessively increasing catering prices $-42.5 \%$ of indications $\left(\mathrm{M}_{\mathrm{pv}}=4.22\right)$, too little greenery-41.9\% of indications $\left(\mathrm{M}_{\mathrm{pv}}=3.91\right)$. In both groups, definitely distinctive positive indications, pointing at favourable features of the impact of tourist traffic on the socioeconomic development of the city, included: attractiveness of the city for tourists-91.3\% of indications $\left(\mathrm{M}_{\mathrm{pv}}=6.12\right)$, high growth rate $-71.2 \%$ of indications $\left(\mathrm{M}_{\mathrm{pv}}=5.11\right)$, intensive functioning of the urban community $-67.5 \%$ of indications $\left(\mathrm{M}_{\mathrm{pv}}=5.05\right)$. Interestingly, the opinions of key experts were more critical but in several points coincided with the views of other experts. The detailed data for the groups of other experts and key experts are presented in Figure 3.

The mean values of the responses confirming the negative impact of the tourist traffic on the socioeconomic situation of the city were $\mathrm{M}_{\mathrm{ro}}=32.5 \%\left(\mathrm{~V}_{\mathrm{o}}=47.2\right)$ for other experts and $\mathrm{M}_{\mathrm{re}}=39.0 \%$ $\left(V_{e}=50.6\right)$ for key experts. The mean result for opinions denying the existence of such symptoms equalled $\mathrm{M}_{\mathrm{ro}}=46.6 \%\left(\mathrm{~V}_{\mathrm{o}}=44.1\right)$ among other experts and $\mathrm{M}_{\mathrm{re}}=38.1 \%\left(\mathrm{~V}_{\mathrm{e}}=69.2\right)$ among key experts. 


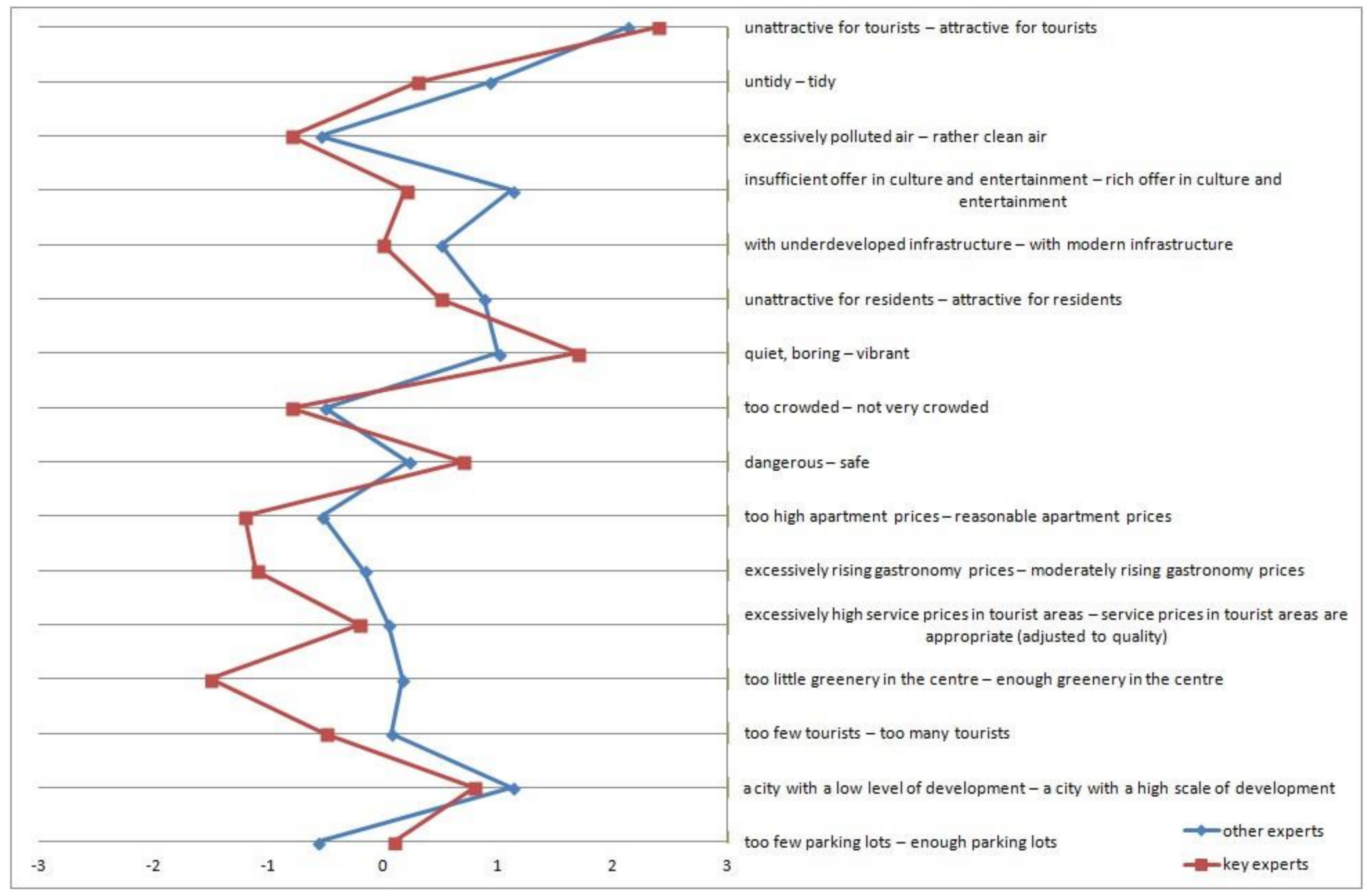

Figure 3. Problems in the socioeconomic development of Wrocław caused by tourist traffic in the opinion of key experts and other experts. Source: own elaboration. 
The dysfunctionality of tourism in the context of negative impact on local communities in areas visited by tourists is currently a serious sociocultural problem, especially in cities and areas of high tourist traffic concentration. Examples of negative interference of tourism with the local environment, in particular with the residents, can also be observed in Wrocław. The identification and analysis of the symptoms, of varying intensity, is of particular importance for determining the strategic directions of the city development, including the reduction of overtourism. The research results indicate that this problem has already been noticed among those who live and work in Wrocław. Almost half of the respondents confirmed the perception of problems in the city functioning that constituted direct or indirect consequences of tourism. Namely, $\mathrm{M}_{\mathrm{ro}}=46.4 \%\left(\mathrm{~V}_{\mathrm{o}}=45.7\right)$ of other experts and $\mathrm{M}_{\mathrm{re}}=43.3 \%$ $\left(\mathrm{V}_{\mathrm{e}}=50.2\right)$ of key experts confirmed and $\mathrm{M}_{\mathrm{ro}}=27.4 \%\left(\mathrm{~V}_{\mathrm{o}}=55.3\right)$ of other experts and $\mathrm{M}_{\mathrm{re}}=34.4 \%$ $\left(\mathrm{V}_{\mathrm{e}}=61.8\right)$ of key experts denied their existence.

The issues most frequently pointed out by both the surveyed other experts and key experts that evidently reflected the already noticeable signs of a conflict between tourists and residents included: limited parking capacity for own means of transport-indicated by about $80 \%$ of the surveyed other experts and key experts, with the mean point values of positive and negative indications for both groups at the level of $\mathrm{M}_{\mathrm{pv}}=4.16$; excessive noise-nearly $70 \%$ of the opinions in both groups confirmed this observation $\left(\mathrm{M}_{\mathrm{pv}}=3.61\right)$; rent and services becoming too expensive in the areas of residence- $67 \%$ of confirming responses among other experts and $60 \%$ among key experts $\left(\mathrm{M}_{\mathrm{pv}}=3.77\right)$. Apart from the dominant opinions of other experts and key experts confirming the symptoms of the tourist traffic impact on the local community, an interesting finding is the residents' declaration of their willingness to move to more modern regions and housing estates of Wrocław- $53 \%$ of confirming responses among other experts and $40 \%$ among key experts $\left(\mathrm{M}_{\mathrm{pv}}=3.37\right)$. One may presume that this case is not related to the negative impact of tourist traffic but to the willingness of daily functioning in the areas currently fulfilling a residential function in the city, at the same time being modern housing estates with a comprehensive socioeconomic infrastructure fully equipped and adapted to the needs of residents. In addition, this observation can be linked to the respondents' opinion on the city safety issues: the sense of security among the city permanent residents turned out moderate. The research revealed an almost even distribution of the respondents who described the city as safe (40.0\% of indications) or unsafe (31.2\% of indications) (Figure 3). Almost 30\% of residents assessed this issue neutrally. Despite such ambiguous views of the residents, with regard to their own safety, most respondents did not notice any issue: they felt safe, as evidenced by nearly half of the subjects- $-46.9 \%\left(\mathrm{M}_{\mathrm{pv}}=2.81\right)$ (Figure 4).

Among the remaining distinctive opinions of respondents who denied specific problems in the functioning of the Wrocław inhabitants, one should mention absence or limitation of retail and service infrastructure- $54.4 \%\left(\mathrm{M}_{\mathrm{pv}}=2.63\right)$ and the lack of objections to sharing daily life in the city with tourists-38.1\% $\left(\mathrm{M}_{\mathrm{pv}}=2.85\right)$. Detailed results are shown in Figures 3 and 4 .

The respondents' opinions regarding the current image of Wrocław from the perspective of tourist traffic features are important (Figure 5). It is remarkable that in no other case did the responses of key experts and other experts turn out to be as convergent as in the assessment of the city image. Strongly distinctive, unanimous views of the respondents on this issue were indications confirming the positive impact of tourist traffic on the city revenue- $-90.6 \%$ of the indications $\left(\mathrm{M}_{\mathrm{pv}}=4.37\right)$, satisfaction with tourists coming to Wrocław-89.4\% of the indications $\left(\mathrm{M}_{\mathrm{pv}}=4.35\right)$, and satisfaction with the city development through tourist activity- $86.9 \%$ of the indications $\left(\mathrm{M}_{\mathrm{pv}}=4.28\right)$. It is worth emphasizing that the respondents defined the city image generally in positive terms-mostly above $70 \%$ of the indications. 


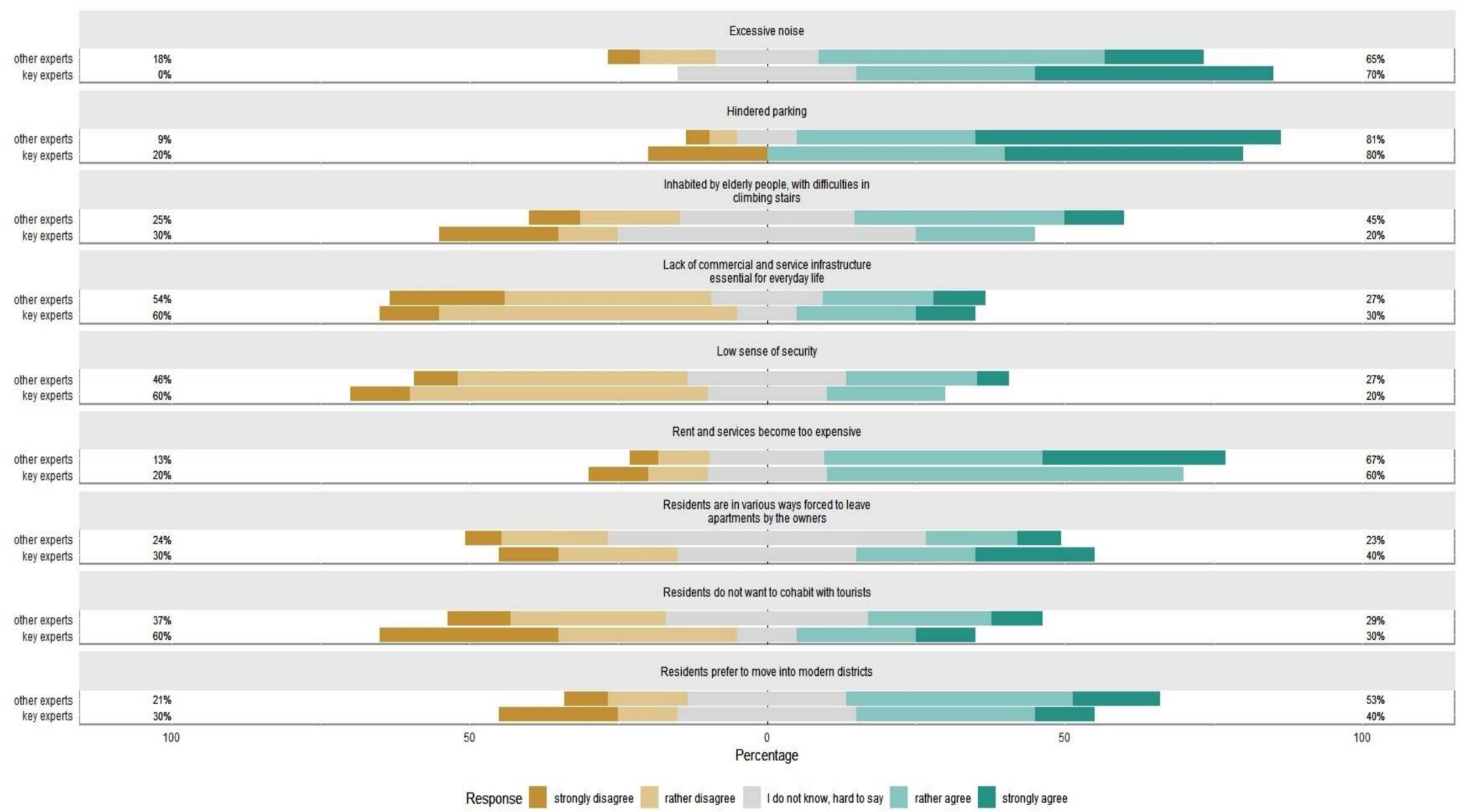

Figure 4. Problematic issues in Wrocław caused by tourist traffic in the opinion of key experts and other experts. Source: own elaboration. 


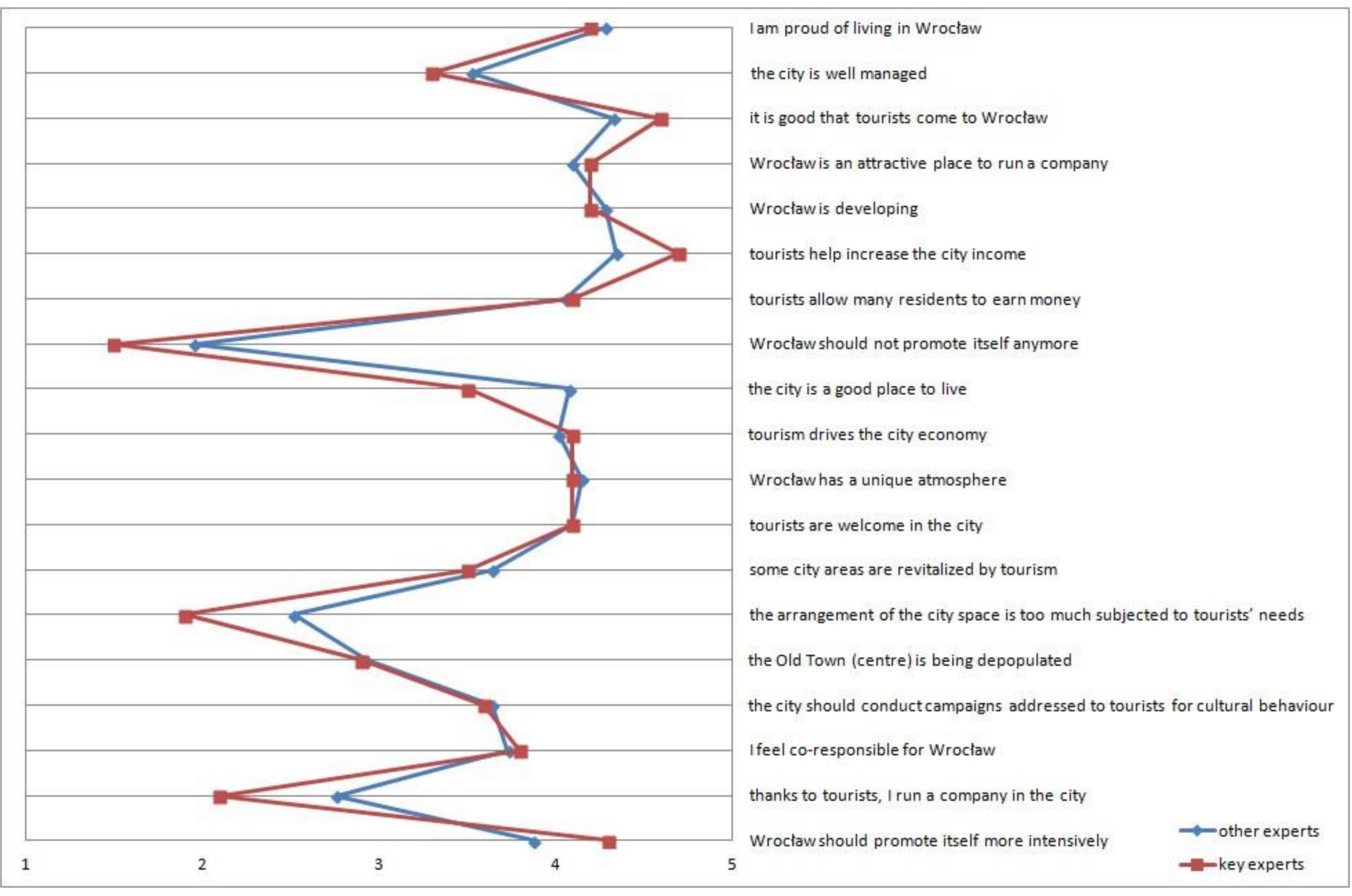

Figure 5. The tourist image of Wrocław in the opinion of key experts and other experts. Source: own elaboration. 
In addition, the respondents were strongly in favour of greater and more intense promotion of the city-almost $80 \%$ of responses $\left(\mathrm{M}_{\mathrm{pv}}=4.07\right)$, and they did not perceive any excessive subordination of the urban space to tourists' needs- $58.7 \%\left(\mathrm{M}_{\mathrm{pv}}=3.52\right)$. The respondents' opinion contradicting the statement provided in the survey was the denial of the impact of tourist traffic on running a business in the city-about $47 \%$ of responses $\left(\mathrm{M}_{\mathrm{pv}}=3.04\right)$. This may indicate a moderate influence of tourism on the economic activity of Wrocław residents, but at the same time it confirms the current observations that the predominance of tourism in the local, regional, or national economy does not necessarily account for the economic potential and strength of the area.

In the assessment of the image of Wrocław, determined by 19 variables (Figure 5), the mean result for opinions confirming its features observed by the respondents was $\mathrm{M}_{\mathrm{ro}}=65.5 \%\left(\mathrm{~V}_{\mathrm{o}}=37.0\right)$ for other experts and $\mathrm{M}_{\mathrm{re}}=62.6 \%\left(\mathrm{~V}_{\mathrm{e}}=47.5\right)$ for key experts. The mean result for opinions denying the positive qualities of the city image equalled $\mathrm{M}_{\mathrm{ro}}=15.0 \%\left(\mathrm{~V}_{\mathrm{o}}=100.3\right)$ among other experts and $\mathrm{M}_{\mathrm{re}}=26.3 \%$ $\left(\mathrm{V}_{\mathrm{e}}=107.6\right)$ among key experts.

An interesting picture of the respondents' views was revealed with regard to the problem of buying out flats and building new apartments by entrepreneurs and the fact that residents rented rooms and apartments to tourists (Figure 6). The mean results for opinions confirming the presented symptoms were $\mathrm{M}_{\mathrm{ro}}=48.7 \%\left(\mathrm{~V}_{\mathrm{o}}=34.1\right)$ among other experts and $\mathrm{M}_{\mathrm{re}}=48.2 \%\left(\mathrm{~V}_{\mathrm{e}}=35.7\right)$ among key experts. The mean rates of negative responses to these statements equalled $M_{r o}=25.0 \%\left(V_{o}=35.9\right)$ for other experts and $\mathrm{M}_{\mathrm{re}}=30.0 \%\left(\mathrm{~V}_{\mathrm{e}}=47.1\right)$ for key experts.

The most distinct statements obtained from respondents in this respect clearly included opinions confirming both positive and negative views of this phenomenon. However, the response rates confirming or denying particular elements of the described phenomenon did not in any case exceed the values of $70 \%$ or $40 \%$, respectively, in the group of other experts and $80 \%$ or $50 \%$, respectively, in the group of key experts. They also did not show any significant differentiation between the two groups. Specifically, the respondents noted rather positive consequences or symptoms of such housing management, in particular in terms of expanding the accommodation base and offer- $66.3 \%$ of responses $\left(\mathrm{M}_{\mathrm{pv}}=3.61\right)$, stimulating housing estates-63.1\% of responses $\left(\mathrm{M}_{\mathrm{pv}}=3.48\right)$, and increasing the earning opportunities for residents $-61.9 \%$ of responses $\left(\mathrm{M}_{\mathrm{pv}}=3.53\right)$. Only in two cases of opinions expressed by respondents was the negative dimension of this process observed. Both other experts and key experts indicated the negative consequences of conducting such activity in Wrocław, in the form of increased prices of residential facilities- $66.9 \%$ of responses $\left(\mathrm{M}_{\mathrm{pv}}=3.76\right)$ and increased living costs for inhabitants- $51.3 \%$ of responses $\left(\mathrm{M}_{\mathrm{pv}}=3.50\right)$. Despite the positive perception of this phenomenon in most opinions, the rates of responses regarding intervention in or restriction of such housing management in the city were almost evenly distributed (50\% in each case). In addition, in this case, similarly to other respondents' assessments of the city image, functioning in the city, or the perceived problems of Wrocław socioeconomic development, there was a strong diversity of indications in particular groups of respondents, expressed in high values of the coefficient of variation. More detailed information on the specific response rates is presented in Figure 6.

The distribution of the response rates among other experts and key experts was statistically significantly different in the case of the statement "There are signs of a negative impact of tourism on the city tourist values" (Figure 2) ( $p=0.009345)$, "too little greenery in the centre" vs. "enough greenery in the centre" (Figure 3) ( $p=0.02412)$, and the question "Are you satisfied with living in Wrocław?" $(p=0.03932)$. The mean point value for the responses to the statement "too little greenery in the centre" vs. "enough greenery in the centre" (Figure 3 ) for other experts and key experts was statistically significantly different $(p=0.0107)$.

On the basis of the obtained results, it should also be noted that $72.5 \%$ of the respondents were satisfied with living in Wrocław and did not intend to move out in the nearest future or change their place of residence $(66.25 \%)$, despite the increased tourist traffic. However, it should be clearly emphasized that almost $34 \%$ of the surveyed were already planning such a migration, which may be caused by the difficulties or limitations in everyday life in the city. 


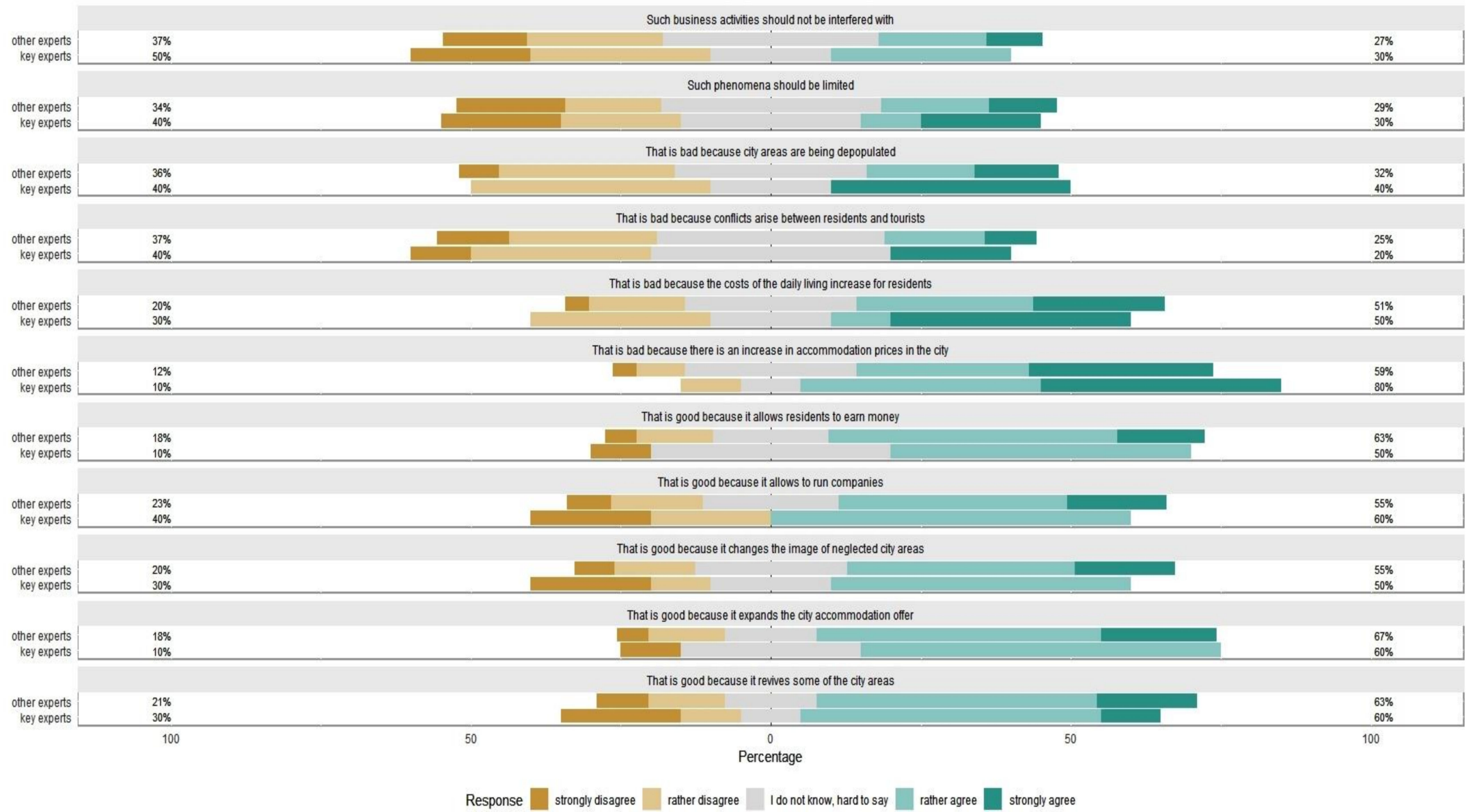

Figure 6. The purchase and construction of apartments by entrepreneurs and renting rooms and apartments by residents for tourists in the opinion of respondents. Source: own elaboration. 
Only about $30 \%$ of the respondents were familiar with the concept of gentrification processes, which can result from overtourism. It is highly probable that the lack of respondents' knowledge of this phenomenon could have contributed to many positive opinions on housing policy and management in Wrocław. At the same time, the basic reasons for the lack of such knowledge should undoubtedly be sought in the lack of contacts or any observations in this respect by the surveyed experts (residents), who mostly lived outside the city centre (nearly $85 \%$ ), where the symptoms of gentrification are typically not present.

Figure 7 illustrates the results of the correlation analysis of the studied variables. The values of the rank correlation coefficients ranged from -0.30 (statistically significant, $p=0$ ) for total scores for the variables presented in Figures 2 and 5 to 0.32 (statistically significant, $p=0$ ) for the variables presented in Figures 3 and 5. Statistically significant low correlations were reported for the pairs of survey questions indicated as variables in pairs presented in Figures 2 and 5, Figures 2 and 4, Figures 3 and 5, and Figures 4 and 6.

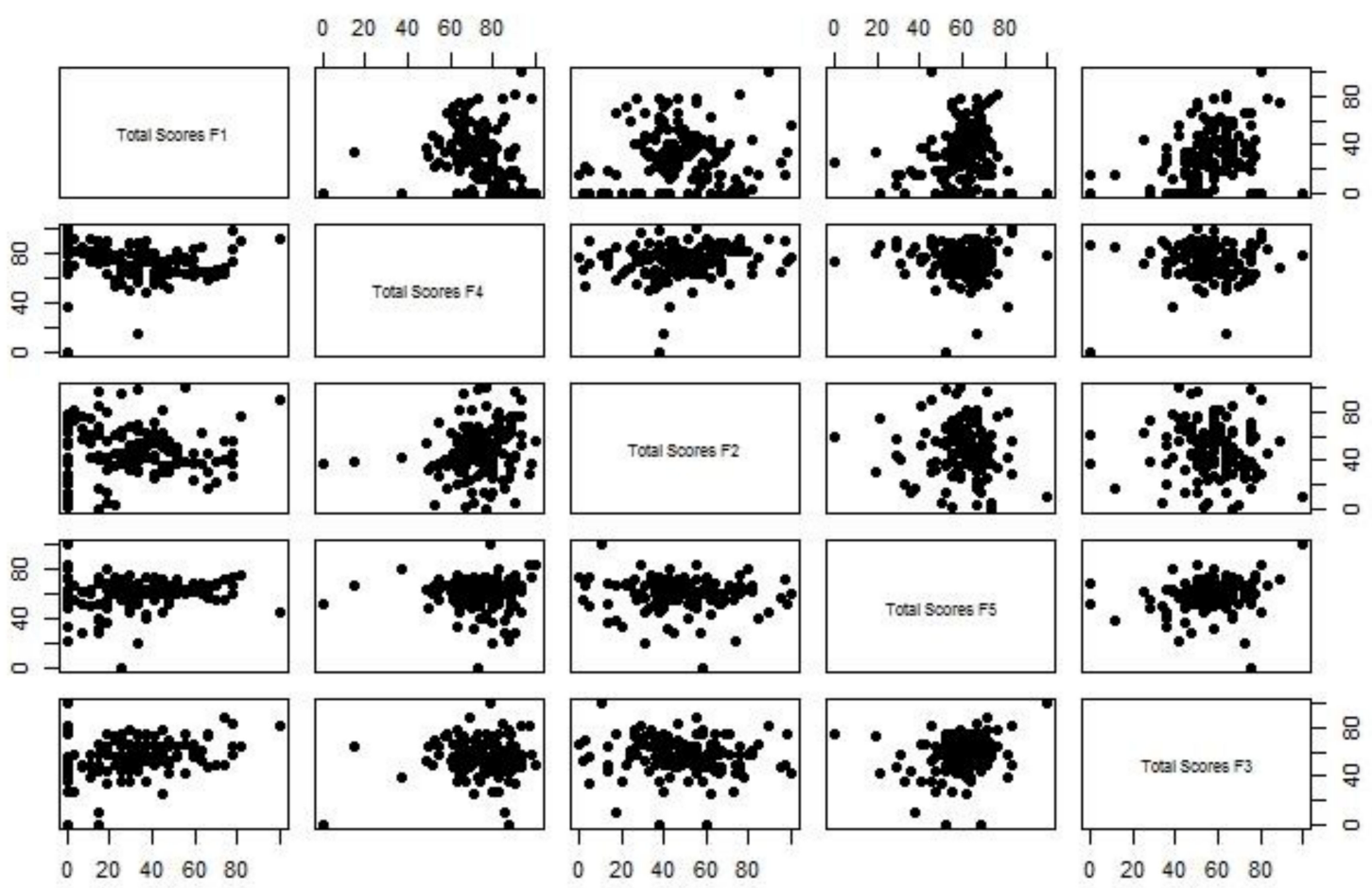

Figure 7. Correlation analyses of the studied variable responses to the survey questions. Source: own elaboration.

Other correlation coefficients for the studied variables did not exceed 0.15 and were not statistically significant (Table 2).

Table 2. Rank correlation matrix for the studied variable groups.

\begin{tabular}{lccccc}
\hline & Figure 1 Scores & Figure 4 Scores & Figure 2 Scores & Figure 5 Scores & Figure 3 Scores \\
\hline F1 scores & 1.00 & -0.30 & -0.09 & 0.15 & 0.30 \\
F4 scores & -0.30 & 1.00 & 0.32 & 0.00 & -0.09 \\
F2 scores & -0.09 & 0.32 & 1.00 & -0.12 & -0.15 \\
F5 scores & 0.15 & 0.00 & -0.12 & 1.00 & 0.27 \\
F3 scores & 0.30 & -0.09 & -0.15 & 0.27 & 1.00 \\
\hline
\end{tabular}

Source: own elaboration. 
Identification of risk factors and assessment of the degree of overtourism threat to urban agglomeration units face a number of methodological problems, including those stemming from the limited possibilities to obtain source data based on the opinions of city residents exposed to overtourism. In turn, the main problem with the interpretation of the overtourism phenomenon is the need to assess risk factors and the level of overtourism threat from various perspectives of tourism stakeholders (inhabitants, entrepreneurs, local authorities, others), whose opinions are frequently contradictory.

\section{Discussion}

The scientific community emphasizes that the processes of excessive concentration of tourist traffic cause disruption or degradation of the sociocultural space in cities and may decrease the quality of life or encourage inhabitants to move out of the city or to other districts not burdened with intensive tourist penetration $[24,52,53]$.

The results of the presented research point at a convergence, though at different levels, of respondents' assessments of the characteristics of tourist traffic negatively affecting the functioning of Wrocław and its inhabitants.

The study allowed for the identification of symptoms indicating the already perceived negative effects of excessively growing tourist traffic on the functioning of Wrocław inhabitants. These include increasing costs of daily living, insufficient number of parking lots, city congestion (especially in recreational areas), excessive noise, excessively rising gastronomy prices and high service prices in tourist areas plus a limited access to them, too high and steadily rising accommodation prices, excessive air pollution, or first symptoms of inhabitants' migration. Similar indicators of negative effects of excessive tourist traffic in urban entities of recognized tourist attractiveness have been indicated, among others, by Innerhofer et al. [54], Kruczek [24], and Milano et al. [26].

The present study, although limited in scope (owing to the sample size resulting from the purposive and qualitative sampling), confirms the preliminary diagnosis that the first symptoms of overtourism in Wrocław are already observed and may intensify in the following years. At the same time, the problem does not currently cause any significant concerns among the respondents (key experts or other experts).

In the context of the research results, several courses of action can be pointed out with due caution (resulting from the limited number of participants), which might limit or decelerate the overtourism phenomenon in Wrocław. Namely, it is essential to:

- develop a strategy to prevent and reduce overtourism as part of a horizontal city development policy;

- include tourism in the city spatial development plans in an interdisciplinary manner;

- diversify the tourist traffic in the city space, i.e., stimulate tourism in subsequent Wrocław districts (less attractive for tourists than the central area of the city);

- diversify and extend the tourist season to reduce tourist traffic seasonality;

- expand the transport system and urban infrastructure, with strict enforcement of the law with regard to the availability of dedicated spaces for servicing tourist traffic (parking lots, pedestrian routes, etc.);

- develop a local policy for temporary property rental, taking into account a well-balanced tourist offer and respect for the needs of residents;

- moderate the development of tourist services and products in cooperation with businesses and networks, taking care of the quality of services and comfort of both tourists and residents;

- limit acts of vandalism, devastation, aggression in points of contact between tourists and residents through a monitoring system, and the activities of municipal services (municipal guard, police);

- $\quad$ enhance the environmental awareness of tourists, residents, and entrepreneurs. 
The proposed directions of action could also be implemented into organizational practice by other cities, especially European ones, with a comparable scale of tourist phenomena as in Wrocław and threatened by overtourism; at least, they could serve as a reference point for comparative analyses.

The attitude towards overtourism among Wrocław inhabitants who are not directly involved in tourism and people who do not draw income from this economic sector has not been covered in this study and remains a problem for further research. The attitudes of residents and tourist business community representatives towards excessive concentration of tourist traffic have been interestingly depicted by Szromek et al. [55] and Kowalczyk-Anioł and Zmyślony [56] in the example of Krakow agglomeration. Analyses of opinions of various types of tourist traffic stakeholders towards the phenomenon of overtourism (including those pointing to a conflict of interests among tourist stakeholders) were also conducted in relation to other Polish cities of high tourist attractiveness, among others, Zakopane and Kazimierz Dolny [57]. The findings of these studies can be a reference point for an in-depth assessment of overtourism in Wrocław.

Kowalczyk-Anioł and Zmyślony [56] indicate that the problem of overtourism, according to those managing urban tourism, does not exist until there emerges a sudden crisis in the relations among the local community, tourists, and the authorities. Thus, the phenomenon of overtourism and its symptoms (including those identified for Wrocław) may, according to the authors, also concern other cities in Poland with similar tourist attractiveness, similar tourist resources and potential, or similar level and degree of saturation of tourist traffic. Such urban centres at risk of overtourism, with due caution in the assessment, already include Gdańsk and Poznań [57].

\section{Conclusions}

1. The tourist development of Wrocław now constitutes a challenge for all tourist traffic stakeholders, including the city authorities. The management of the Wrocław agglomeration, an interesting tourist destination, should focus on finding a concept of sustainable development, using forms of sustainable tourism, and based on measures to prevent or at least mitigate the effects of overtourism. This postulate should also apply to other agglomerations supporting their development through the use of tourism. The tendency of stakeholders to measure success by means of tourism growth [58] is the issue that one should rethink at first while solving the problem of overtourism.

2. The threats identified in the study that result from the increased tourist traffic are consistent with those implied in the strategy for the development of tourism in Wrocław, especially with regard to the observed increase in the volume of tourist traffic; concentration of tourist traffic in the city centre, with insufficient use of the potential and resources of other Wrocław regions; growing inefficiency of the transport system (an uncontrolled rise in the number of cars, permanent traffic jamming); growing environmental risks (air pollution, resulting in the discomfort of resting in the city); and the deficit of investments in tourist infrastructure and a modern tourist information system, limiting the tourists' sense of security [1].

3. We point at the need to examine and evaluate the development strategies of other cities with a developed tourist function in Poland and Europe. The aim of such investigations may be to verify the local authorities' awareness of factors indicating the threat of overtourism in the space of a given city.

4. The trends and characteristics of the tourism market observed in urban tourism demand a change of tourism development planning towards a qualitative rather than a quantitative approach. The latter is often misinterpreted as one of the biggest "overtourism enablers" [22], bound with a currently very popular (and lucrative for a few "pockets") inclination to sustain the tourism growth $[59,60]$.

5. The concept of tourism economy development adopted by the Wrocław authorities is focused on maintaining an adequate volume of tourist traffic, changing its structure, extending the length of stay, and reducing seasonality, which would allow for a more sustainable development of the city and for controlling tourism from the position of the city authorities [1]. It is worth mentioning that 
according to Milano et al. [25], "city administrators and destination managers must acknowledge that there are definite limits to growth. Prioritising the welfare of local residents above the needs of the global tourism supply chain is vital. Prime consideration must be given to ensuring that the level of visitation fits within a destination's capacity". In this context, the step that should be taken by the city authorities as part of overtourism prevention and implementation of sustainable development principles in tourism is to define the carrying capacity of Wrocław.

6. Besides, it is necessary to emphasize the creation of modern and well-designed public spaces (expansion of tourism beyond the city centre), which would improve the quality of the tourist offer and would effectively address the dangers of excessive concentration of tourist traffic and gentrification phenomena in the city centre. Szromek et al. [55] postulate tourist traffic management that would allow for quick and effective responses to changes, by implementing the concept of agile tourism, defined as adjusting organizational culture and quickly responding to market changes [61].

7. There are different levels of knowledge about factors and processes shaping tourist traffic in urban agglomerations. Undoubtedly, we should recommend the need for a broad dialogue among all stakeholders of the tourist traffic regarding the positive and negative tourist factors that affect the city functioning. A broad dialogue of circles making use of tourist traffic and all other inhabitants should become a standard of action in all city entities and should be inspired by the city authorities or the local scientific community.

8. The search for synergy of interests among tourism stakeholders should become a priority for the entire tourist environment, by meeting the needs and expectations of residents, who should be fully involved in the development of tourism, along with education that includes the ability to perceive the phenomenon of overtourism and understand it properly. The potential increase (which has been diagnosed in other cities) in conflicts of interest between tourist entrepreneurs and local residents as a result of uncontrolled growth of tourist traffic leads to difficulties in managing the urban agglomeration and may affect the tourist image of the city in the future.

\section{Limitations and Further Research}

The conducted survey research, and, previously, an in-depth analysis of the subject literature and available sources of data on tourist traffic and overtourism (in Wrocław, as well as other cities) induce the following conclusions:

- The research provides an added value as it made it possible to effectively use methodological assumptions in the form of accepted methods of measuring excessive concentration of tourist traffic, with the obvious reservation as to the quantitative scale of the survey-here, the number of respondents.

- The results can be applied as a reference point in further research in the field of overtourism in Wrocław or other cities with a similar scale of tourist traffic and level of attractiveness and with a similar potential of resources serving the development of the sphere of tourism with the application of the sustainable development concept.

- Monitoring tourist traffic from different perspectives should be a strategic challenge and goal for local politicians, managers, researchers, and other stakeholders.

Author Contributions: Conceptualization, W.F., J.O., M.S.; methodology, W.F., J.O., M.S.; software, W.F., M.S., A.M.; validation, W.F., J.O., M.S., K.B., A.M.; formal analysis, W.F., J.O., M.S.; investigation, W.F., M.S.; resources, W.F., J.O., M.S., K.B., A.M.; data curation, W.F., M.S., A.M.; writing - original draft preparation, W.F., J.O., M.S., K.B.; writing - review and editing, W.F., J.O., M.S., K.B., A.M.; visualization, W.F., M.S., A.M.; supervision, W.F., M.S.; project administration, W.F., M.S.; funding acquisition, W.F., M.S. All authors have read and agreed to the published version of the manuscript.

Funding: This research received funding from the University School of Physical Education in Wrocław. 
Conflicts of Interest: The authors declare no conflict of interest. The funders had no role in the design of the study; in the collection, analyses, or interpretation of data; in the writing of the manuscript; or in the decision to publish the results.

\section{References}

1. Olearnik, J.; Oleśniewicz, P.; Fedyk, W.; Pluta, J. Koncepcja Rozwoju Turystyki We Wrocławiu Do 2023 Roku; Urząd Miasta Wrocławia: Wrocław, Poland, 2017.

2. BEELINE Research \& Consulting. Badanie Ruchu Turystycznego We Wrocławiu; Urząd Miasta Wrocławia: Wrocław, Poland, 2018.

3. Opracowanie koncepcji metodologicznej oraz wykonania badań ilościowych i jakościowych ruchu turystycznego na Dolnym Ślasku. Available online: http://www.przetargi.egospodarka.pl/593154_ Opracowanie-koncepcji-metodologicznej-oraz-wykonanie-badan-ilosciowych-i-jakosciowych-ruchuturystycznego-na-Dolnym-Slasku-w-ukladzie-powiatowym_2019_2.html (accessed on 26 February 2020).

4. The World According to GaWC 2018. Available online: https:/www.lboro.ac.uk/gawc/world2018t.html (accessed on 3 January 2020).

5. Premium Brand. Wrocław Miastem z Najwyższą Reputacją-Znamy Wyniki Premium Brand 2019. Available online: http://www.premiumbrand.com.pl/aktualnosci/miasta-2019 (accessed on 3 January 2020).

6. IESE. Cities in Motion Index 2019. Available online: https://media.iese.edu/research/pdfs/ST-0509-E.pdf (accessed on 3 January 2020).

7. Purvis, B.; Mao, Y.; Robinson, D. Three pillars of sustainability: In search of conceptual origins. Sustain. Sci. 2019, 14, 681-695. [CrossRef]

8. Buckley, R. Sustainable tourism: Research and reality. Ann. Tour. Res. 2012, 39, 528-546. [CrossRef]

9. Butler, R.W. Tourism, environment, and sustainable development. Environ. Conserv. 1991, 18, $201-209$. [CrossRef]

10. Butler, R.W. Sustainable tourism: A state-of-the-art review. Tour. Geogr. 1999, 1, 7-25. [CrossRef]

11. Clarke, J. A framework of approaches to sustainable tourism. J. Sustain. Tour. 1997, 5, 224-233. [CrossRef]

12. Hardy, A.; Beeton, R.J.S.; Pearson, L. Sustainable tourism: An overview of the concept and its position in relation to conceptualisations of tourism. J. Sustain. Tour. 2002, 10, 475-496. [CrossRef]

13. Lu, J.; Nepal, S.K. Sustainable tourism research: An analysis of papers published in the Journal of Sustainable Tourism. J. Sustain. Tour. 2009, 17, 5-16. [CrossRef]

14. Kowalczyk, A. Turystyka Zrównoważona; Wydawnictwo Naukowe PWN: Warszawa, Poland, 2010.

15. Niezgoda, A. Obszar recepcji turystycznej w warunkach rozwoju zrównoważonego. Prace Habilitacyjne Akad. Ekon. Poznaniu 2006, 24.

16. Maxim, C. Sustainable tourism implementation in urban areas: A case study of London. J. Sustain. Tour. 2016, 24, 971-989. [CrossRef]

17. Paunović, I.; Jovanović, V. Implementation of sustainable tourism in the German Alps: A case study. Sustainability 2017, 9, 226. [CrossRef]

18. Rodrigues, A.L.O.; Rodrigues, A.; Peroff, D.M. The sky and sustainable tourism development: A case study of a Dark Sky Reserve implementation in Alqueva. Int. J. Tour. Res. 2015, 17, 292-302. [CrossRef]

19. Rutty, M.; Richardson, R.B. Tourism research in Cuba: Gaps in knowledge and challenges for sustainable tourism. Sustainability 2019, 11, 3340. [CrossRef]

20. Gołembski, G. Kompendium Wiedzy o Turystyce, 2nd ed.; Wydawnictwo Naukowe PWN: Warszawa, Poland, 2009.

21. Niezgoda, A.; Markiewicz, E. Turystyka biznesowa a turystyka zrównoważona - przykład hotelu w aglomeracji. Zesz. Nauk. WSB Pozn. 2015, 63, 226-240.

22. Dodds, R.; Butler, R.W. Overtourism: Issues, Realities and Solutions; De Gruyter: Berlin, Germany, 2019.

23. Dredge, D. “Overtourism” Old Wine in New Bottles? Available online: https://www.linkedin.com/pulse/ overtourism-old-wine-new-bottles-dianne-dredge (accessed on 6 December 2019).

24. Kruczek, Z. Ways to counteract the negative effects of overtourism at tourist attractions and destinations. Ann. Univ. Mariae Curie Sklodowska B Geogr. Geol. Miner. Petrogr. 2019, 74, 45-57. [CrossRef]

25. Milano, C.; Cheer, J.M.; Novelli, M. Overtourism: A Growing Global Problem. 2018. Available online: https: //sg.news.yahoo.com/overtourism-growing-global-problem-120301587.html (accessed on 3 January 2020). 
26. Milano, C.; Cheer, J.M.; Novelli, M. Overtourism: Excesses, Discontents and Measures in Travel and Tourism; CABI: Boston, MA, USA, 2019.

27. Séraphin, H.; Zaman, M.; Olver, S.; Bourliataux-Lajoinie, S.; Dosquet, F. Destination branding and overtourism. J. Hosp. Tour. Manag. 2019, 38, 1-4. [CrossRef]

28. Milano, C. Overtourism and Tourismphobia: Global Trends and Local Contexts; Ostelea School of Tourism \& Hospitality: Barcelona, Spain, 2017.

29. World Tourism Organization (UNWTO). Overtourism?-Understanding and Managing Urban Tourism Growth beyond Perceptions, Executive Summary. Available online: https://www.unwto.org/global/ publication/overtourism-understanding-and-managing-urban-tourism-growth-beyond-perceptionsexecutive (accessed on 26 February 2020).

30. The International Ecotourism Society. Ecotourism Is the Solution to Overtourism. 2019. Available online: https://ecotourism.org/news/ecotourism-is-the-solution-to-overtourism/ (accessed on 3 January 2020).

31. Becker, E. Overbooked. In The Exploding Business of Travel and Tourism; Simon \& Schuster: New York, NY, USA, 2013.

32. World Travel and Tourism Council. Destination 2030: Global Cities' Readiness for Tourism Growth. Available online: https://www.wttc.org/publications/2019/destination-2030/ (accessed on 3 January 2020).

33. Kruczek, Z. Turyści vs Mieszkańcy. Wpływ Nadmiernej Frekwencji Turystów na Proces Gentryfikacji Miast Historycznych na Przykładzie Krakowa. Available online: http://turystykakulturowa.org/ojs/index.php/tk/ article/view/956 (accessed on 26 February 2020).

34. Gretzel, U.; Fesenmaier, D.R.; Formica, S.; O'Leary, J. Searching for the future: Challenges faced by destination marketing organizations. J. Traval Res. 2006, 45, 116-126. [CrossRef]

35. Klimek, K. Destination management organisations and their shift to sustainable tourism development. Eur. J. Tour. Hosp. Recreat. 2013, 4, 27-47.

36. Müller, H.; Berger, P. Benchmarking for destination management organizations: The case of Swiss cities and Alpine destination management. Tour. Rev. 2012, 67, 26-39. [CrossRef]

37. Pike, S. Consumer-based brand equity for destinations. J. Travel Tour. Mark. 2007, 22, 51-61. [CrossRef]

38. Pike, S.; Page, S.J. Destination marketing organizations and destination marketing: A narrative analysis of the literature. Tour. Manag. 2014, 41, 202-227. [CrossRef]

39. Presenza, A.; Sheehan, L.; Ritchie, J.R.B. Towards a model of the roles and activities of destination management organizations. J. Hosp. Tour Leis. Sci. 2005, 3, 1-16.

40. Zins, A.H. Internal benchmarking for regional tourism organizations: A case example. Tour. Anal. 2014, 19, 413-424. [CrossRef]

41. Kowalczyk, A. Od turystyki 3S do turystyki 3E. In Turystyka Wobec Zmian Wspótczesnego Świata. Zmiany, Bariery, Innowacje; Gołembski, G., Niezgoda, A., Eds.; Wydawnictwo Uniwersytetu Ekonomicznego w Poznaniu: Poznań, Poland, 2014.

42. Balińska, A.; Sieczko, A.; Zawadka, J. Turystyka: Wybrane zagadnienia; Difin: Warszawa, Poland, 2014.

43. Wearing, S.; McGehee, N.G. International Volunteer Tourism: Integrating Travellers and Communities; CABI: Boston, MA, USA, 2013.

44. Fennell, D.A. Ecotourism; Routledge: Abingdon, UK, 2015.

45. Wearing, S.; Schweinsberg, S. Ecotourism: Transitioning to the 22nd Century; Routledge: Abingdon, UK, 2018.

46. Fischer, A. Sustainable Tourism; UTB GmbH: Bern, Switzerland, 2014.

47. Zaręba, D. Ekoturystyka, 3rd ed.; Wydawnictwo Naukowe PWN: Warszawa, Poland, 2010.

48. Galar, R.; Roman, G.; Waszkiewicz, J. Strategia, Wrocław w perspektywie 2020 plus; Urząd Miasta Wrocławia: Wrocław, Poland, 2006.

49. Strategia Wrocław 2030. Available online: https:/www.wroclaw.pl/rozmawia/strategia-wroclaw-2030 (accessed on 3 December 2019).

50. R Core Team. R: A Language and Environment for Statistical Computing. Available online: https: //www.r-project.org/ (accessed on 26 February 2020).

51. Bryer, J.; Speerschneider, K. Likert: Analysis and Visualization Likert Items. 2016. Available online: https://rdrr.io/cran/likert/ (accessed on 26 February 2020).

52. Peeters, P.; Gössling, S.; Klijs, J.; Milano, C.; Novelli, M.; Dijkmans, C.; Eijgelaar, E.; Hartman, S.; Heslinga, J.; Isaac, R.; et al. Research for TRAN Committee-Overtourism: ćImpact and Possible Policy Responses; European Parliament, Policy Department for Structural and Cohesion Policies: Brussels, Belgium, 2018. 
53. Walas, B. Turystyczny Najem Krótkoterminowy w Ocenie Interesariuszy Lokalnych. Available online: http://journals.pan.pl/Content/115435/PDF/049_062_Walas.pdf?handler=pdf (accessed on 3 February 2020).

54. Innerhofer, E.; Erschbamer, G.; Pechlaner, H. Overtourism: The Challenge of Managing the Limits. In Overtourism: Tourism Management and Solutions; Pechlaner, H., Innerhofer, E., Erschbamer, G., Eds.; Routledge: New York, NY, USA, 2019.

55. Szromek, A.R.; Kruczek, Z.; Walas, B. The attitude of tourist destination residents towards the effects of overtourism-Kraków case study. Sustainability 2019, 12, 228. [CrossRef]

56. Kowalczyk-Anioł, J.; Zmyślony, P. Turystyka miejska jako źródło protestów społecznych: Przykłady Wenecji i Barcelony. Kowalczyk Anioł Piotr Zmyślony 2017, 2, 7-36.

57. Gnieźnieńskie Forum Ekspertów Turystyki Kulturowej. Overoturism w Turystyce Kulturowej. Available online: www.turystykakulturowa.org (accessed on 19 February 2020).

58. Becken, S.; Simmons, D.G. Stakeholder Management: Different Interests and Different Actions. In Overtourism: Issues, Realities and Solutions; Dodds, R., Butler, R., Eds.; De Gruyter: Berlin, Germany, 2019.

59. Higgins-Desbiolles, F. Sustainable tourism: Sustaining tourism or something more? Tour. Manag. Perspect. 2018, 25, 157-160. [CrossRef]

60. Monbiot, G. How "Sustainability" Became "Sustained Growth". 2012. Available online: https://www. monbiot.com/2012/06/22/how-sustainability-became-sustained-growth/ (accessed on 20 February 2020).

61. Cheer, J.M.; Lew, A. Understanding Tourism Resilience: Adapting to Social, Political, and Economic Change. In Tourism, Resilience, and Sustainability: Adapting to Social, Political and Economic Change; Cheer, J.M., Lew, A., Eds.; Routledge: Abingdon, UK, 2017; Available online: https://www.researchgate.net/publication/319059213_ Understanding_tourism_resilience_Adapting_to_social_political_and_economic_change (accessed on 3 February 2020).

(C) 2020 by the authors. Licensee MDPI, Basel, Switzerland. This article is an open access article distributed under the terms and conditions of the Creative Commons Attribution (CC BY) license (http://creativecommons.org/licenses/by/4.0/). 